Matteo Riccó ${ }^{1}$

Carlo Signorelli $i^{2}$

Enrico Pistelli ${ }^{3}$

Silvia Cattani ${ }^{4}$

\title{
QUANTITATIVE OLFACTORY DISORDERS AND OCCUPATIONAL EXPOSURE TO PHENOLIC RESINS
}

\author{
ILOŚCIOWE ZABURZENIA WĘCHU A NARAŻENIE ZAWODOWE NA ŻYWICE FENOLOWE
}

\author{
${ }^{1}$ Provincial Agency for Health Services in Trento, Trento, Italy \\ Unit for Health and Safety on the Workplaces, Department of Prevention \\ ${ }^{2}$ University of Parma, Parma, Italy \\ Department of Biomedical, Biotechnological, and Translational Sciences \\ ${ }^{3}$ Industria Abrasivi Parmense - Globe Srl, Parma, Italy \\ ${ }^{4}$ Parma University Hospital, Parma, Italy \\ Department of Clinical Surgery, General Surgery and Surgical Therapy, School of Nursing Sciences
}

\begin{abstract}
Background: To investigate whether exposure to phenolic resins (PR) is associated with quantitative olfactory disorders (QOD), a cross-sectional study of self-reported olfactory impairment (SROI) was performed in occupationally exposed subjects. Material and Methods: Sixty-six workers ( 45 males, 21 females) at the age (mean \pm standard deviation) of $39.8 \pm 10.15$ years old were divided into 3 exposure groups on the basis of biological exposure indices (BEI) for urinary phenols. It was asked whether the sense of smell has been normal or abnormal during the recent 2 months: the participants were eventually divided into self-reported normosmic, hyposmic, hyperosmic groups. Results: Prevalence of the SROI was 45.5\%, with 21 (31.8\%) workers complaining about the hyposmia, $12(18.2 \%)$ - anosmia and $9(13.6 \%)$ - hyperosmia. In univariate analyses, female sex was associated with the SROI and the hyperosmia. Highly exposed workers showed the SROI more frequently (odds ratio $(O R)=4.714$; $95 \%$ confidence interval (CI): 1.077-20.626) than those not exposed (reference) or low exposed (OR $=1.333 ; 95 \% \mathrm{CI}: 0.416-4.274)$. In multivariate analyses, female sex was the main risk factor for the SROI (adjusted odds ratio $(\mathrm{OR})=5.622$; 95\% CI: $1.525-20.722)$ and the hyperosmia $\left(\mathrm{OR}_{\mathrm{a}}=25.143 ; 95 \%\right.$ CI: 2.379-265.7) but a high exposure to phenol $\left(\mathrm{OR}_{\mathrm{a}}=11.133 ; 95 \%\right.$ CI: $\left.1.060-116.9\right)$ was the main risk factor for the anosmia. Conclusions: This study has found slight evidence among the cross-section of chemical industry workers that the exposure to phenol may be associated with the SROI. On the other hand, self-reporting of the QOD may be biased by personal factors and further research with objective measurement is therefore required. Med Pr 2016;67(2):173-186
\end{abstract}

Key words: biological markers, industrial psychology, olfaction disorders, phenol-formaldehyde resins, olfactory mucosa, formaldehyde

\section{STRESZCZENIE}

Wstęp: Celem badania przekrojowego było określenie zależności między zawodową ekspozycją na żywice fenolowe (phenolic resins - PR) a ilościowymi zaburzeniami węchu (quantitative olfactory disorders - QOD), tj. zgłaszanymi przez pacjentów upośledzeniami węchu (self-reported olfactory impairment - SROI). Materiał i metody: Sześćdziesięciu sześciu pracowników (45 mężczyzn, 21 kobiet) w wieku (średnia \pm odchylenie standardowe) 39,8 $\pm 10,15$ roku podzielono na 3 grupy na podstawie wartości oznaczanych w moczu wskaźników narażenia biologicznego (biological exposure indices - BEI) dla fenoli. Następnie w zależności od zaburzeń węchu - ich braku lub występowania w ciągu ostatnich 2 miesięcy - badanych podzielono na grupy: normosmiotyczną, hiposmiotyczną i hiperosmiotyczną. Wyniki: Upośledzenie węchu zgłosiło łącznie 30 badanych (45,5\%), w tym hiposmię - 21 osób (31,8\%), anosmię - 12 osób (18,2\%) i hiperosmię - 9 osób (13,6\%). Analiza jednoczynnikowa wykazała, że istnieje zależność między płcią żeńską a występowaniem SROI i hiperosmii. Ponadto SROI było częstsze u pracowników z grupy wysokiego narażenia zawodowego na fenole (iloraz szans - odds ratio $(\mathrm{OR})=4,714$; 95\% przedział ufności - confidence interval (CI): 1,077-20,626) niż z grupy niskiego narażenia $(\mathrm{OR}=1,333$; 95\% CI: 0,416-4,274) i pracowników nienarażonych (grupa referencyjna). Także analiza wieloczynnikowa wykazała, że płeć żeńska jest głównym czynnikiem ryzyka SROI (skorygowany iloraz szans - adjusted odds ratio $\left(\mathrm{OR}_{\mathrm{a}}\right)=5,622 ; 95 \%$ CI: 1,525-20,722) i hiperosmii $\left(\mathrm{OR}_{\mathrm{a}}=25,143 ; 95 \%\right.$ CI: 2,379-265,7), natomiast wysokie narażenie na fenol - anosmii $\left(\mathrm{OR}_{\mathrm{a}}=11,133 ; 95 \%\right.$ CI: 1,060-116,9). Wnioski: Badanie dostarczyło słabych dowodów na istnienie zależności między narażeniem pracowników przemysłu chemicznego na fenol a występowaniem SROI. Na wyniki badania ilościowych zaburzeń węchu (QOD) przeprowadzonego z użyciem ankiety mogły wpłynąć czynniki indywidualne, dlatego koniecznie są dalsze badania z zastosowaniem obiektywnych metod pomiaru. Med. Pr. 2016;67(2):173-186

Słowa kluczowe: markery biologiczne, psychologia przemysłowa, zaburzenia węchu, żywice fenolowo-formaldehydowe, błona węchowa, formaldehyd 
Corresponding author / Autor do korespondencji: Matteo Riccó, Provincial Agency for Health Services in Trento, Unit for Health and Safety on the Workplaces, Department of Prevention, Via Verona SNC (C/O Centro Servizi Sanitari), 38123 Trento, Italy, e-mail: mricco2000@gmail.com, matteo.ricco@apss.tn.it

Received: September 3, 2015, accepted: December 1, 2015

\section{INTRODUCTION}

Olfactory disorders (OD) are generally dichotomized in qualitative (parosmia, phantosmia, olfactory agnosia) and quantitative olfactory disorders (QODs: hyposmia, anosmia, hyperosmia). The prevalence of the QODs in the general population is disputed but it presumptively ranges $1-20 \%$ [1-3], with higher values represented by men and progressively increasing values with age in both sexes [4-6]. The most common QOD is the hyposmia, the decreased ability to smell, the prevalence of which in general population is up to $16 \%$ [3]. The anosmia i.e., the lack of ability to smell, is also quite frequent: about $5 \%$ of general population exhibit functional anosmia but several studies suggest an even greater prevalence, with a self-reported anosmia varying between $1.4-15 \%[7,8]$. The hyperosmia i.e., the enhanced ability to smell, is rare and frequently associated with the exposure to toxic vapors or neurologic disorders such as migraine $[9,10]$.

Quantitative olfactory disorders (QODs) usually constitute the acquired dysfunction of the olfactory system: post-infectious olfactory loss, post-traumatic olfactory loss, chronic rhinosinusitis account for up to $2 / 3$ of all cases [10]. In general, all noxae able to induce inflammation of the olfactory epithelium (OE) appear particularly detrimental to the olfactory function: reactive intermediates (e.g., reactive oxygen intermediates - ROIs) exhibit a significant toxic effect to the olfactory receptors either directly or indirectly [5-7,9-11].

Many airborne chemicals or their metabolites elicit high levels of the ROIs in the OE. In 1986, Amoore identified more than 120 chemicals associated with the OD, and since this early description this list has significantly broadened [11,12]. Unsurprisingly, professional exposure is suspected to be causative in the case of $0.5-5 \%$ of all of the OD $[13,14]$. This prevalence is possibly underestimated, especially among subjects having chronic long-term and low-level exposure, in the case of which the olfactory function may decrease gradually and unnoticed. It is possible that a significant part of the "idiopathic" OD (i.e., 10-25\%) may be workrelated $[4,15,16]$.
Phenolic resins (PRs) are synthetic polymers obtained by the reaction of phenol or phenol substituted for formaldehyde, and are used in myriad industrial products and processes (e.g., plywood, construction, automotive and appliance industries, manufacture of nylon and epoxy resins, etc.) [17]. Handling of the PRs is associated with a significant exposure to phenol $\left(\mathrm{C}_{6} \mathrm{H}_{6} \mathrm{O}, 94 \mathrm{~g} / \mathrm{mol}\right.$ in molecular weight $)$ - phenol is a nucleophilic xenobiotic, and when it interacts with mucous membrane it is prone to lose an electron and form free radicals in a reaction catalyzed by peroxidases [18]. Inhalation and dermal exposure to phenol is therefore highly irritating to the surface rich in detoxification enzymes, such as eyes and airways.

In the OE, Bowman's gland cells and supporting cells express many types of peroxidases and detoxification enzymes: because the total amount of the $\mathrm{OE}$ is small in comparison with other organs such as kidney and liver, the total metabolizing capacity of the nasal mucosa may appear lilliputian but, after each organ is normalized to prove the total tissue protein content, the OE activity largely exceeds the liver $[10-13,15]$. Unsurprisingly, studies about occupational exposure to the PRs showed a significant ability to impair the olfactory function [19-21]. Odor threshold for phenol is relatively low $\left(0.04 \mathrm{ppm}\right.$ or $\left.0.154 \mathrm{mg} / \mathrm{m}^{3}\right)$, with a strong sweet odor reported [12] - as the exposure to strong fragrances notoriously affects the olfactory detection [22], it is then possible that the reported impairment of the olfactory function may bring about the combination of biochemical and psychological effects.

For example, an earlier case control study on 100 furniture workers exposed both to the PRs and wood dusts, 70 chemical workers from the plant where formaldehyde and formaldehyde-based products were produced and 36 non-exposed chemical workers, identified a significant decrease in the sense of smell $(\mathrm{p}<0.01)$ in both exposed groups [21]. A subsequent study on 15 workers handling wood fibers with interspersed carbamide resin glue, containing formaldehyde (exposure: $0.8-3.8 \mathrm{mg} / \mathrm{m}^{3}$ for wood dusts, $0.17-0.48 \mathrm{mg} / \mathrm{m}^{3}$ for formaldehyde) and deprived of phenol, 29 wood workers (exposure: $0.3-1 \mathrm{mg} / \mathrm{m}^{3}$ for wood dusts, 0.08 $0.34 \mathrm{mg} / \mathrm{m}^{3}$ for formaldehyde) and 36 non-exposed wor- 
kers, confirmed a very high prevalence for the QOD in both exposed groups (pooled odds ratio $(\mathrm{OR})=10.3$; 95\% confidence interval (CI): 2.19-48.5), emphasizing a suspected causative role for formaldehyde [21].

Formaldehyde is a well-known toxicant for olfactory epithelium and respiratory mucosa [23]. In 2006, the International Agency for Research on Cancer classified formaldehyde as a human carcinogen based on an increase in nasopharyngeal cancer in the cohort of more than 25000 formaldehyde workers as reported by the National Cancer Institute, and in 2012 the classification was expanded with formaldehyde causing leukemia and limited evidence of sinonasal cancer in humans [17,24-26]. Following these reports, professional exposures have been more strictly controlled, where possible by reducing the total content of formaldehyde in chemical intermediates or by improving collective and personal protective equipment.

In summary, studies about olfactory effects of phenol and the PRs in a context of low level formaldehyde exposures are missing. In this study we present our data about self-reported olfactory impairment (SROI) in workers in the abrasive industry professionally exposed to the PRs.

\section{MATERIAL AND METHODS}

\section{Subjects and occupational settings}

This was a cross-sectional study performed in a medium-sized enterprise in northern Italy, that involved the preparation of solid-state resin bond abrasives (SSRBA).
Instead of a more typical water-based wetting agent, in the case of the SSRBA the initial mixture is enriched with the PRs in order to improve the abrasive grains' adhesion, and to guarantee the application on a rigid support (usually, a disk) for specific technical instruments (e.g., grinding wheels). Because formaldehyde has been recognized as an occupational carcinogen since the early 1990s, production of the SSRBA has required previous substitution of safer products for the PRs, that would have the lowest technically permissible content of formaldehyde. In order to further minimize the personal exposure, high-gain ventilation systems were put in place. Eventually, periodic environmental and personal sampling strategies were introduced. This investigation was performed after the most recent overhauling of the ventilation system (December 2013).

At the time of the survey, a total of 66 workers (45 males, 21 females; age (mean $(\mathrm{M}) \pm$ standard deviation (SD)): $39.8 \pm 10.15$ years old; exposure length $(\mathrm{M} \pm \mathrm{SD}): 7.29 \pm 6.52$ years) were employed. On the basis of their exposures and job tasks, workers were divided into 3 exposure groups (Table 1):

mixing plant and continuous ovens,

production plant,

shipping plant.

The first group consisted of 15 workers (10 males, 5 females; 3 smokers; age $(\mathrm{M} \pm \mathrm{SD})$ : $38.20 \pm 11.36$ years old; time of employment in the abrasive industry $(\mathrm{M} \pm \mathrm{SD}): 6.20 \pm 6.13$ years). In the mixing plant, the industrial process begins with the preparation of the desired mixture: precise quantities of abrasives, bond

Table 1. Characteristics of workers occupationally exposed to airborne chemicals at working site

Tabela 1. Charakterystyka pracowników narażonych na substancje chemiczne występujące w powietrzu środowiska pracy

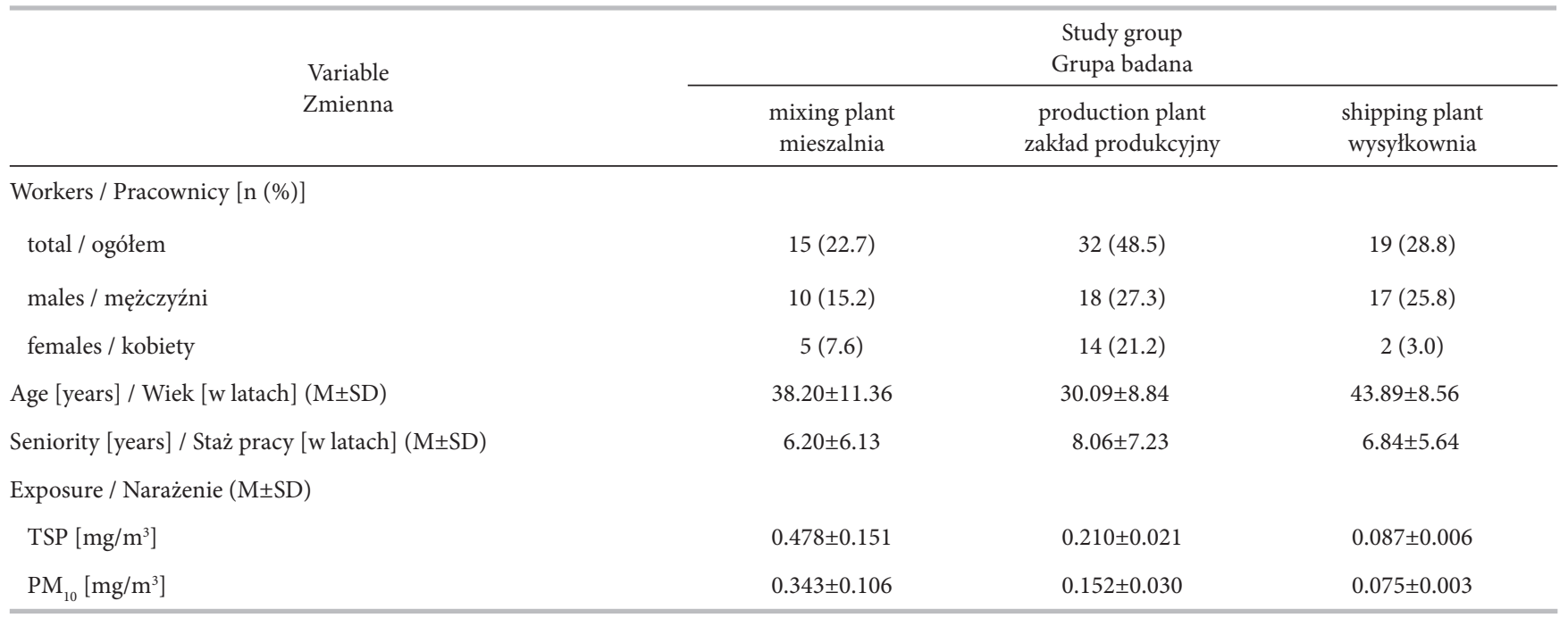


Table 1. Characteristics of workers occupationally exposed to airborne chemicals at working site - cont.

Tabela 1. Charakterystyka pracowników narażonych na substancje chemiczne występujące w powietrzu środowiska pracy - cd.

\begin{tabular}{|c|c|c|c|}
\hline \multirow{2}{*}{$\begin{array}{l}\text { Variable } \\
\text { Zmienna }\end{array}$} & \multicolumn{3}{|c|}{$\begin{array}{l}\text { Study group } \\
\text { Grupa badana }\end{array}$} \\
\hline & $\begin{array}{l}\text { mixing plant } \\
\text { mieszalnia }\end{array}$ & $\begin{array}{l}\text { production plant } \\
\text { zakład produkcyjny }\end{array}$ & $\begin{array}{c}\text { shipping plant } \\
\text { wysyłkownia }\end{array}$ \\
\hline \multicolumn{4}{|l|}{ Exposure / Narażenie $(\mathrm{M} \pm \mathrm{SD})$ - cont. / cd. } \\
\hline $\mathrm{PM}_{2.5}\left[\mathrm{mg} / \mathrm{m}^{3}\right]$ & $0.037 \pm 0.008$ & $0.022 \pm 0.001$ & $0.016 \pm 0.001$ \\
\hline particles / cząstki 0.5-5 $\mu \mathrm{m}[\mathrm{n}]$ & $2493.9 \pm 1437.3$ & $496.0 \pm 36.9$ & $223.5 \pm 15.4$ \\
\hline particles / cząstki < $0.5 \mu \mathrm{m}[\mathrm{n}]$ & $47092.5 \pm 10949.9$ & $27944.1 \pm 955.4$ & $20277.3 \pm 117.2$ \\
\hline formaldehyde / formaldehyd $\left[\mathrm{mg} / \mathrm{m}^{3}\right]$ & $0.04 \pm 0.04$ & $0.03 \pm 0.02$ & $<0.03$ \\
\hline phenol / fenol $\left[\mathrm{mg} / \mathrm{m}^{3}\right]$ & $0.9 \pm 0.02$ & $<0.4$ & $<0.4$ \\
\hline \multicolumn{4}{|l|}{ Ethnic origin / Pochodzenie etniczne [n (\%)] } \\
\hline non-EUR-WHO / poza EUR-WHO & $8(12.1)$ & $17(25.7)$ & $12(18.2)$ \\
\hline EUR-WHO & $7(10.6)$ & $15(22.7)$ & $7(10.6)$ \\
\hline \multicolumn{4}{|l|}{ Education level / Wykształcenie [n (\%)] } \\
\hline$\leq 5$ years / lat & $4(6.1)$ & $8(12.1)$ & $4(6.1)$ \\
\hline $6-8$ years / lat & $4(6.1)$ & $8(12.1)$ & $7(10.6)$ \\
\hline $9-13$ years / lat & $7(10.6)$ & $16(24.2)$ & $8(12.1)$ \\
\hline head trauma / uraz głowy & $7(10.6)$ & $8(12.1)$ & $5(7.6)$ \\
\hline head surgery / operacja głowy & $2(3.0)$ & $1(1.5)$ & 0 \\
\hline nasal trauma / uraz nosa & $5(7.6)$ & $7(10.6)$ & $4(6.1)$ \\
\hline nasal surgery / operacja nosa & $4(6.1)$ & $3(4.5)$ & $2(3.0)$ \\
\hline \multicolumn{4}{|l|}{$\begin{array}{l}\text { Chronic nasal mucosa (olfactory/respiratory) inflammation/ } \\
\text { symptoms / Przewlekłe zapalenie błony śluzowej nosa (związane } \\
\text { Z węchem lub układem oddechowym) lub jego objawy [n (\%)] }\end{array}$} \\
\hline nasal discharge / wydzielina $\mathrm{z}$ nosa & $1(1.5)$ & 0 & 0 \\
\hline post-nasal discharge / wydzielina nosowo-gardłowa & $1(1.5)$ & 0 & 0 \\
\hline nasal breathing disorders / zaburzenia oddychania przez nos & $2(3.0)$ & 0 & $2(3.0)$ \\
\hline ear fullness / uczucie pełności w uchu & $1(1.5)$ & 0 & $2(3.0)$ \\
\hline facial pain/pressure / ból/napięcie twarzy & 0 & $4(6.1)$ & 0 \\
\hline headache / ból głowy & $1(1.5)$ & $1(1.5)$ & $1(1.5)$ \\
\hline
\end{tabular}

TSP - total suspended particles / cząstki pyłu zawieszonego ogółem, PM - particulate matter / cząstki pyłu zawieszonego, ACGIH BEI - American Conference of Governmental Industrial Hygienists biological exposure indices / wskaźniki narażenia biologicznego wg Amerykańskiej Konferencji Rządowych Higienistów Przemysłowych, EUR-WHO World Health Organization European Region / Światowa Organizacja Zdrowia - region europejski.

$\mathrm{M}$ - mean / średnia, SD - standard deviation / odchylenie standardowe. 
materials and additives are prepared following a specific formula, the composition of which depends on the physical properties of the planned final product. The mixture is then treated in continuous ovens, achieving its polymerization in a solid intermediate.

The second group consisted of 32 workers of the production plant (18 males, 14 females; 5 smokers; age $(\mathrm{M} \pm \mathrm{SD}): 30.09 \pm 8.84$ years old; time of employment in the abrasive industry $(\mathrm{M} \pm \mathrm{SD}): 8.06 \pm 7.23$ years), where solid intermediate from the ovens of the mixing plant is shattered and reduced to fine dusts. A predetermined amount of abrasive dusts is poured into a mold: a series of thermal treatment and hydraulic press then compacts the abrasive mixture to the final shape. The PRs adhesives intermixed to the abrasive mixture and the high pressures applied guarantee the application on the required rigid support. In comparison with the mixing plant, the PRs are not directly handled by machineries or workers: therefore, phenol exposure follows the contamination from nearby continuous environments or evaporation from the intermediates, eventually resulting in a reduced exposure.

The third group was a reference group of 19 subjects from the shipping plant of the same enterprise (17 males, 2 females; 5 smokers; age $(\mathrm{M} \pm \mathrm{SD})$ : $43.89 \pm 8.56$ years old; time of employment in the abrasive industry $(\mathrm{M} \pm \mathrm{SD})$ : $6.84 \pm 5.64$ years). In this unit, the abrasive media are labeled, packaged, and finally shipped to national and international distributors. The shipping plant consists of a contiguous but separate site, and the assigned workers don't have any direct exposure to chemical intermediates.

\section{Examination methods}

All subjects underwent detailed medical interviews and physical examinations: because the Italian Law on Occupational Health and Safety (Legislative Decree No. 81/2008) enforces mandatory controls about drug abuse in selected categories, and all workers were considered as a high risk group, a urinary drug test was also performed, excluding cases of cocaine or other neurotropic drug chronic abuse.

A questionnaire was distributed in the course of the medical examination in order to explore smoking and drinking habits, general diseases (diabetes mellitus, hypertension, heart disease, liver disease, depression, cancer), medication habits, and previous head and/or nose trauma. In particular, patients were asked whether sense of smell had been normal or abnormal (abolished/reduced/increased) during the last 2 months.
Participants were also asked to refer when the olfactory symptoms had started and whether symptoms exhibited a work-related trend, increasing during shift work and reducing during the weekends or holidays. Symptoms associated with inflammatory involvement of olfactory/respiratory mucosa of the nose and sinuses (in particular: headache, nasal congestion, swelling of the lips) were also collected and similarly described. Participants rated the impact of the OD on quality of life also on a visual analog scale of 0 (no effect) to 5 (strong effect).

\section{Exposure assessment}

Environmental sampling was performed during a whole working day, on the same day of biological monitoring. Airborne dusts were sampled in all working environments by means of a direct reading instrument (Aerocet 531 Particulate Monitor, Met One Instruments Inc., USA): a total of 8 samples were taken for every site, with a continuous sampling time of $2 \mathrm{~min} / \mathrm{sample}$. Results were expressed in terms of the concentration $\left(\mathrm{mg} / \mathrm{m}^{3}\right)$ for total suspended particles (TSP), particulate matter with aerodynamic caliber $<10 \mu \mathrm{m}\left(\mathrm{PM}_{10}\right),<2.5 \mu \mathrm{m}$ $\left(\mathrm{PM}_{2.5}\right),<1 \mu \mathrm{m}\left(\mathrm{PM}_{1}\right)$ and as a count $\left(\right.$ particles $\left./ \mathrm{m}^{3}\right)$ for particles with aerodynamic caliber $0.5-5 \mu \mathrm{m}$ and $<0.5 \mu \mathrm{m}$.

Airborne concentrations of phenol and formaldehyde were measured according to the standards set out by the National Institute for Occupational Safety and Health (NIOSH). Formaldehyde was sampled using the NIOSH method 3500, whereas the NIOSH method 2546 was applied for the purpose of the environmental assessment of phenol [27-28].

In the same week of the clinical evaluation of the participants, all workers from the mixing plant, production plant and shipping plant participated in biological monitoring. The urinary samples were collected in polycarbonate bottles at the end of their work shift $(8 \mathrm{~h} /$ day $)$ at the end of the working week and stored at $-4^{\circ} \mathrm{C}$. Measurement of phenol in urine was carried out by means of the high performance liquid chromatography. The results were presented after correction for creatinine concentration ( $\mathrm{mg} / \mathrm{g}$ creatinine). The creatinine was measured by means of an autoanalyzer based on the Jaffe's method.

\section{Statistical analysis}

Descriptive statistics were used for the demographic characteristics and the self-reported olfactory symptoms. Continuous variables were confronted through 
the analysis of variance (ANOVA) and the post-hoc test of Tukey's for multiple comparisons. Statistical significance was defined by a two-sided a level of 0.05 .

Multivariate logistic regression analyses were performed to examine association between self-reported olfactory symptoms and phenol exposure, categorized in the aforementioned exposure classes (the mixing plant, production plant, shipping and packaging plant). The multivariate regression analysis was modeled on the basis of occupational exposure: workers from the plant with the lowest occupational exposure were assumed as the referent ones. Associations were expressed in terms of the ORs with their respective 95\% CI. Eventually, the regression analysis was controlled for ethnicity, years of education, age and working age determining the adjusted ORs (OR $)$ with their respective 95\% CI.

All calculations were performed on the IBM SPSS Statistics 22.

\section{RESULTS}

\section{Environmental sampling}

As compared with other sites, the mixing plant had significantly higher concentrations for $(\mathrm{M} \pm \mathrm{SD})$ : TSP $\left(0.478 \pm 0.151 \mathrm{mg} / \mathrm{m}^{3}\right), \mathrm{PM}_{10}\left(0.343 \pm 0.106 \mathrm{mg} / \mathrm{m}^{3}\right), \mathrm{PM}_{2.5}$ $\left(0.037 \pm 0.008 \mathrm{mg} / \mathrm{m}^{3}\right)$ and $\mathrm{PM}_{1}\left(0.004 \pm 0.001 \mathrm{mg} / \mathrm{m}^{3}\right.$; in all cases - the ANOVA $\mathrm{p}<0.0001$ and Tukey's multiple comparison test $\mathrm{p}<0.0001)$. Moreover, concentration of airborne particles in the production plant $\left((\mathrm{M} \pm \mathrm{SD}) \quad \mathrm{TSP}: \quad 0.210 \pm 0.021 \mathrm{mg} / \mathrm{m}^{3}, \quad \mathrm{PM}_{10}: \quad 0.152 \pm\right.$ $0.030 \mathrm{mg} / \mathrm{m}^{3}, \mathrm{PM}_{2.5}: 0.022 \pm 0.001 \mathrm{mg} / \mathrm{m}^{3} ; \mathrm{PM}_{1}: 0.003 \pm$ $0.001 \mathrm{mg} / \mathrm{m}^{3}$ ) was regularly higher than in the shipping plant $\left((\mathrm{M} \pm \mathrm{SD}) \quad \mathrm{TSP}: \quad 0.087 \pm 0.006 \mathrm{mg} / \mathrm{m}^{3}\right.$, $\mathrm{PM}_{10}: 0.075 \pm 0.003 \mathrm{mg} / \mathrm{m}^{3}, \mathrm{PM}_{2.5}: 0.016 \pm 0.001 \mathrm{mg} / \mathrm{m}^{3}$; $\mathrm{PM}_{1}: 0.002 \pm 0.001 \mathrm{mg} / \mathrm{m}^{3}$ ) but the difference was not significant for the $\mathrm{PM}_{10}$ (Figure 1).

Similarly, the particles count was significantly higher in the mixing plant for both exposure categories 0.5-5 $\mu \mathrm{m}\left((\mathrm{M} \pm \mathrm{SD}) 2493.9 \pm 1437.3 / \mathrm{m}^{3}\right.$ vs. $496 \pm 36.9 / \mathrm{m}^{3}$ and $223.5 \pm 15.4 / \mathrm{m}^{3}$ in the production and shipping plant, respectively) and $<0.5 \mu \mathrm{m}((\mathrm{M} \pm \mathrm{SD}) 47092.5 \pm$ $10949.9 / \mathrm{m}^{3}$ vs. $27944.1 \pm 955.4 / \mathrm{m}^{3}$ and $20277.3 \pm$ $117.2 / \mathrm{m}^{3}$; in both cases the ANOVA $\mathrm{p}<0.0001$ and Tukey's multiple comparison test $\mathrm{p}<0.0001$ for comparison with the production and shipping plant). Eventually, the particles count for the production plant and shipping plant was not significantly different (Figure 2, Table 1).

In all sites (the mixing plant, production plant and shipping plant) environmental measurements for as- sessed chemicals were generally low. In particular, concentrations of formaldehyde were $0.04 \pm 0.04 \mathrm{mg} / \mathrm{m}^{3}$ for the mixing plant, $0.03 \pm 0.02 \mathrm{mg} / \mathrm{m}^{3}$ for the production plant and $<0.04 \mathrm{mg} / \mathrm{m}^{3}$ for the shipping plant (the threshold limit value set out by the American Conference of Governmental Industrial Hygienists - the short-term exposure limit - (ACGIH TLV-STEL): $0.37 \mathrm{mg} / \mathrm{m}^{3}$ ) whereas environmental phenol concentrations stood at $0.9 \pm 0.2 \mathrm{mg} / \mathrm{m}^{3}$ for the mixing plant and $<0.4 \mathrm{mg} / \mathrm{m}^{3}$ for all the other sites (the ACGIH's threshold limit value - the time-weighted average (ACGIH TLV-TWA): $19 \mathrm{mg} / \mathrm{m}^{3}$ ).

\section{Biological monitoring}

In all cases, end-shift biological exposure indices (BEIs) were lower than the ACGIH-BEI $(250 \mathrm{mg} / \mathrm{g}$ of creatinine), and the mixing plant workers were associated with significantly higher urine phenol concentrations $(83.80 \pm 19.57 \mathrm{mg} / \mathrm{g}$ of creatinine, ANOVA: $\mathrm{p}<0.0001$; Tukey's multiple comparison test: $\mathrm{p}<0.01$ for the production plant and $<0.0001$ for the shipping plant) whereas the production plant workers had intermediate values $(34.49 \pm 20.77 \mathrm{mg} / \mathrm{g}$ of creatinine), still significantly higher than the shipping plant workers $(6.83 \pm 5.75 \mathrm{mg} / \mathrm{g}$ of creatinine, Tukey's multiple comparison test: $\mathrm{p}<0.01)$ (Table 1).

\section{Risk factors for olfactory impairment}

Out of the 66 participants, 27 subjects (40.9\%) were active or former smokers (i.e., at least 5 years of exposure) (Table 1); 9 patients (13.6\%) referred to previous surgical procedures involving the nose or nasal sinuses; 16 of them $(24.2 \%)$ had a previous nasal trauma with hemorrhage and 20 of them (30.3\%) referred to a head trauma with transitory loss of conscience, including 3 workers who received a surgical treatment requiring craniotomy. No significant differences in the distribution of these risk factors were identified among the three exposure groups (Table 1). Symptoms associated with upper airways inflammatory involvement were scarcely referred to: in general, only 1 subject from the mixing plant group referred to chronic nasal discharge (1.5\%), and 4 more subjects complained about chronic nasal breathing disorders (6.1\%) (Table 1). These factors also appeared to have been distributed among the three exposure groups without any significant difference.

\section{Assessment of olfactory function}

In total, 30 subjects (45.5\%) identified a mild to severe impairment of olfactory function, including 21 sub- 
a)

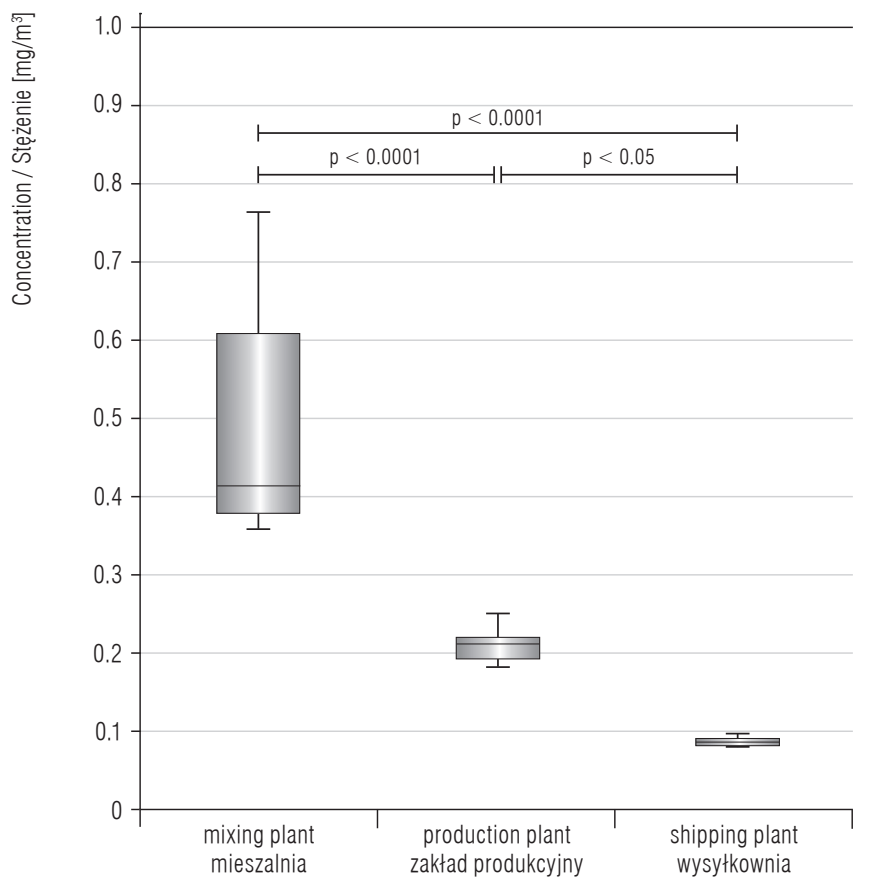

Working site / Miejsce pracy

c)

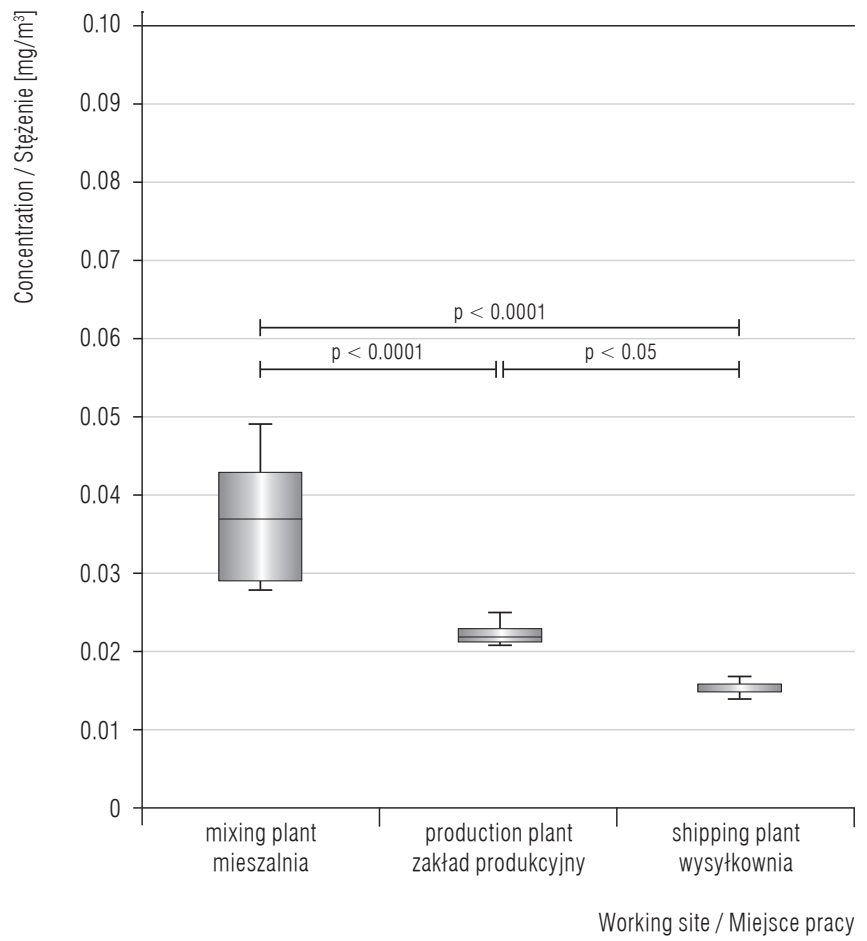

b)

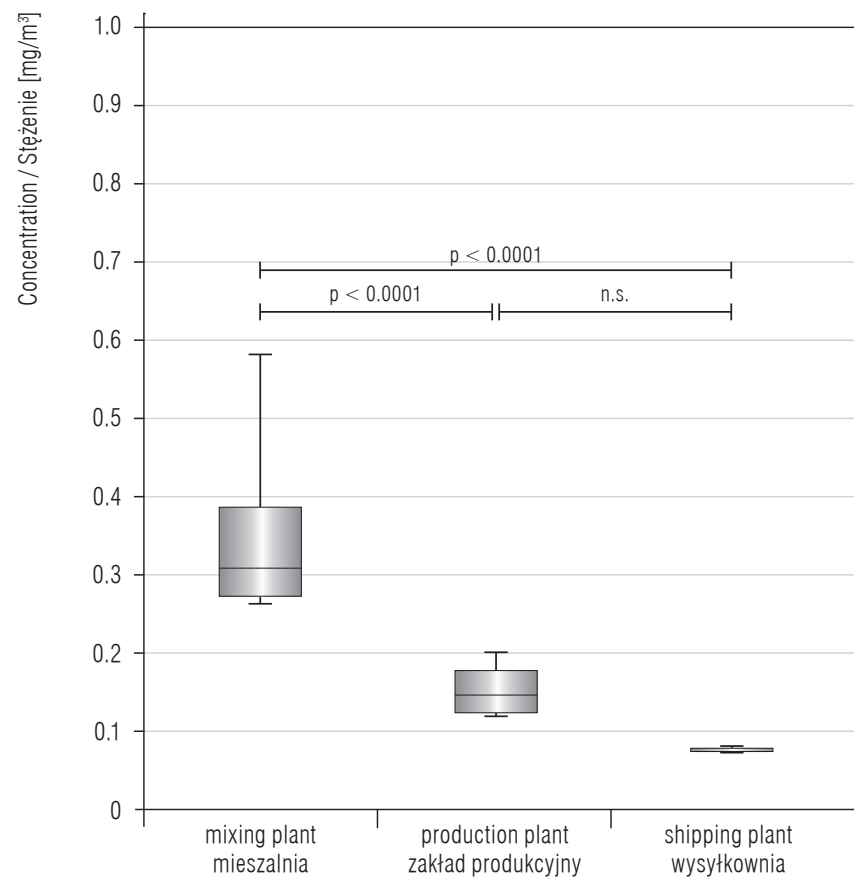

Working site / Miejsce pracy

d)

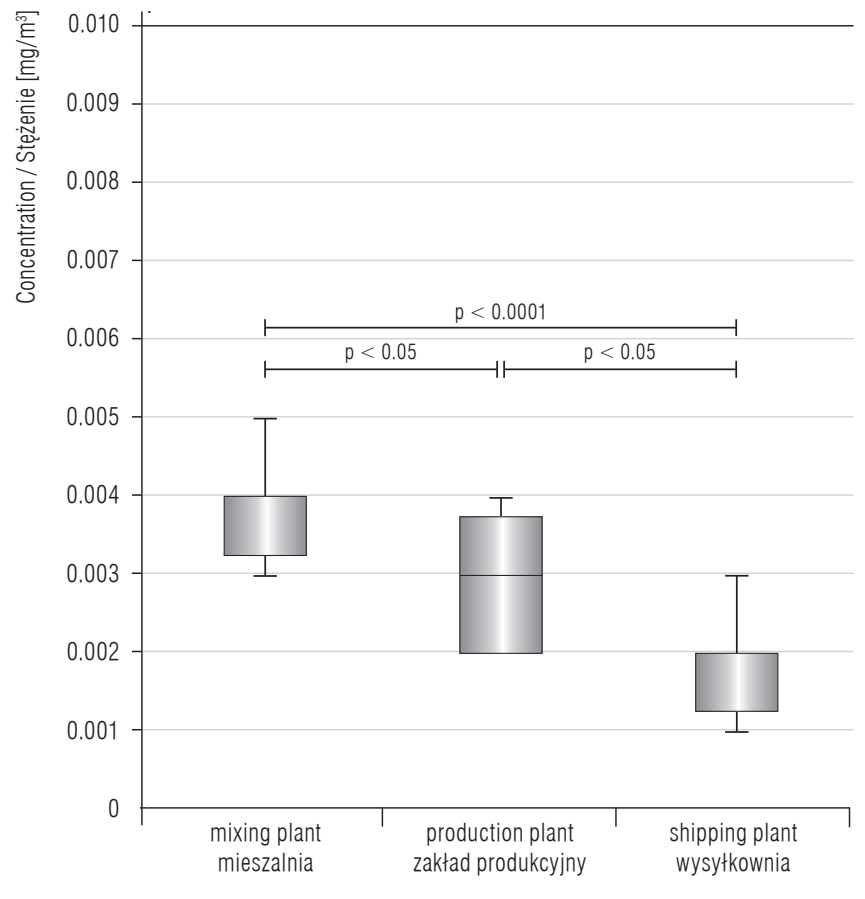

Working site / Miejsce pracy

n.s. - not statistically significant / nieistotne statystycznie.

Results were confronted through analysis of variance (ANOVA) and post-hoc test of Tukey's for multiple comparisons / Wyniki zestawiono poprzez analizę wariancji (ANOVA) i test post-hoc Tukeya w celu porównania wieloczynnikowego.

Fig. 1. Airborne dust by working site: a) total suspended particles (TSP), b) particles with aerodynamic caliber $<10 \mu \mathrm{m}\left(\mathrm{PM}_{10}\right)$, c) $\mathrm{PM}_{2.5}$, and d) $\mathrm{PM}_{1}$

Ryc. 1. Pył w powietrzu w zależności od miejsca pracy badanych: a) cząstki pyłu zawieszonego ogółem (TSP), b) cząstki o średnicy aerodynamicznej $\left.<10 \mu \mathrm{m}\left(\mathrm{PM}_{10}\right), \mathrm{c}\right) \mathrm{PM}_{2.5}$ i d) $\mathrm{PM}_{1}$ 
a)

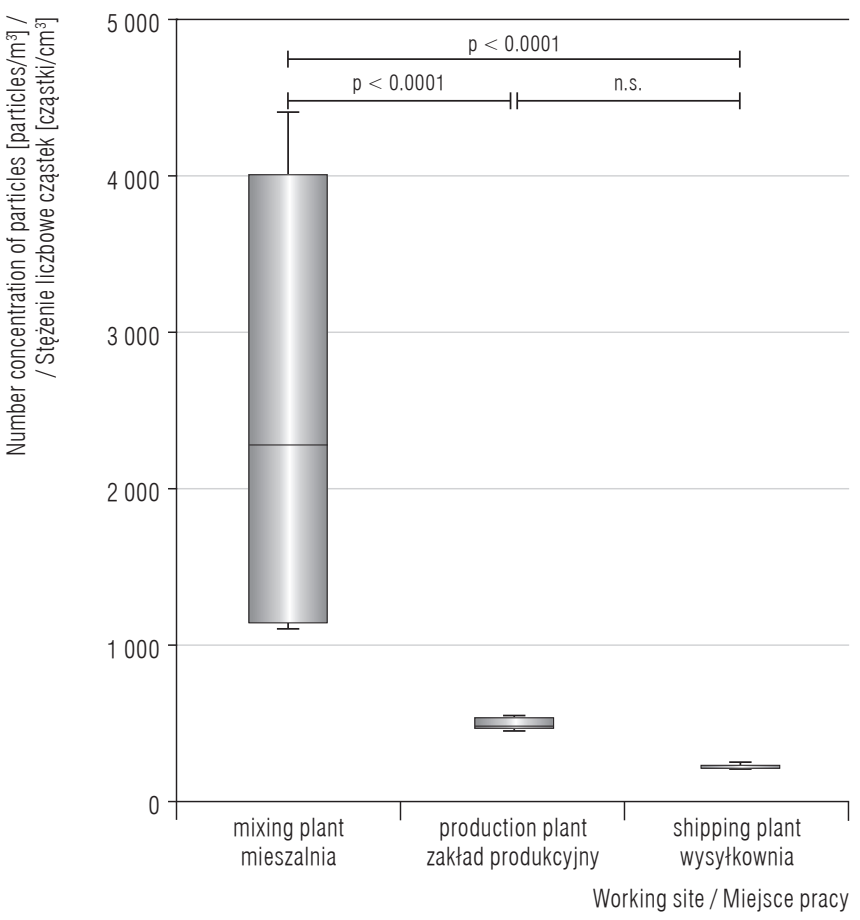

b)

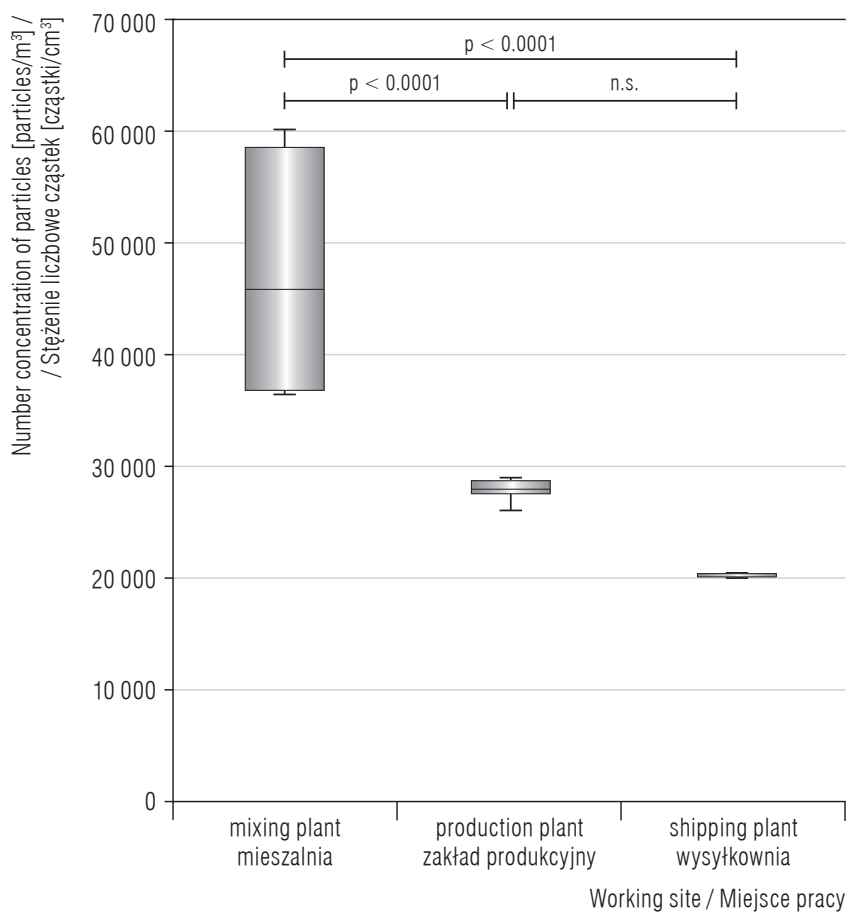

Abbreviations as in Figure 1/ Objaśnienia jak w rycinie 1.

Fig. 2. Airborne dust by working site of respondents: a) particles with aerodynamic caliber $0.5-5 \mu \mathrm{m}$ and b) particles $<0.5 \mu \mathrm{m}$ Ryc. 2. Pył w powietrzu w zależności od miejsca pracy badanych: a) cząstki o średnicy aerodynamicznej $0,5-5 \mu \mathrm{m}$ i b) cząstki $<0,5 \mu \mathrm{m}$

jects $(31.8 \%)$ referring to a reduced sense of smell (hyposmia): in the case of 9 of them, the olfactory function was reduced but not abolished, and the remaining 12 of them complained about a substantial anosmia (18.2\%). Moreover, 9 workers (13.6\%) complained about an increased sense of smell (hyperosmia) (Table 2). Among the hyposmic participants, only the subjects with anosmia referred to a severe impact on the daily life whereas 7/9 hyperosmic patients had a moderate to severe impairment. A work-related time trend was identified, with worsening of the SROI during the work shift/working week and improving at rest $\left(\mathrm{Chi}^{2}\right.$ test $\mathrm{p}<0.0001$ for all the three categories).

In univariate analyses (Table 3), the SROI were significantly more frequent among female subjects $\left(\mathrm{Chi}^{2}\right.$ test $\left.\mathrm{p}=0.022 ; \mathrm{OR}=4.118 ; 95 \% \mathrm{CI}: 1.34-12.65\right)$,

Table 2. Self-assessed ${ }^{a}$ impact of self-reported olfactory impairment (SROI) of workers occupationally exposed to phenolic resins on the quality of life

Tabela 2. Samoocena ${ }^{a}$ wpływu zgłaszanego upośledzenia węchu (SROI) na jakość życia przez pracowników zawodowo narażonych na żywice fenolowe

\begin{tabular}{|c|c|c|c|c|c|c|c|c|c|}
\hline \multirow{2}{*}{$\begin{array}{l}\text { Olfactory impairment } \\
\text { Upośledzenie węchu }\end{array}$} & \multirow{2}{*}{$\begin{array}{l}\text { SROI } \\
\text { (total) } \\
\text { (ogółem) } \\
{[\mathrm{n}(\%)]}\end{array}$} & \multicolumn{6}{|c|}{$\begin{array}{l}\text { Impact of SROI on daily life } \\
\text { Wpływ SROI na życie codzienne } \\
\text { [n (\%)] }\end{array}$} & \multirow{2}{*}{$\begin{array}{c}\text { Symptoms } \\
\text { worsen } \\
\text { at work } \\
\text { Objawy } \\
\text { pogarszające się } \\
\text { w pracy } \\
\text { [n (\%)] }\end{array}$} & \multirow{2}{*}{$\begin{array}{c}\text { Symptoms } \\
\text { improve } \\
\text { at rest } \\
\text { Objawy } \\
\text { ustępujące } \\
\text { po odpoczynku } \\
\text { [n (\%)] }\end{array}$} \\
\hline & & $\begin{array}{c}\text { no } \\
\text { brak }\end{array}$ & $\begin{array}{c}\text { scarce } \\
\text { niewielki }\end{array}$ & $\begin{array}{c}\text { mild } \\
\text { łagodny }\end{array}$ & $\begin{array}{c}\text { moderate } \\
\text { umiarkowany }\end{array}$ & $\begin{array}{l}\text { substantial } \\
\text { znaczny }\end{array}$ & $\begin{array}{c}\text { severe } \\
\text { poważny }\end{array}$ & & \\
\hline Hyposmia / Hiposmia & $21(31.8)$ & $2(3.0)$ & $1(1.5)$ & $3(4.5)$ & $9(13.6)$ & $3(4.5)$ & $3(4.5)$ & $12^{*}(18.2)$ & $11^{*}(16.7)$ \\
\hline Anosmia & $12(18.2)$ & $2(3.0)$ & $1(1.5)$ & $1(1.5)$ & $4(6.1)$ & $1(1.5)$ & $3(4.5)$ & $8^{\star}(12.1)$ & $6^{*}(4.5)$ \\
\hline Hyperosmia / Hiperosmia & $9(13.6)$ & $1(1.5)$ & - & $1(1.5)$ & $3(4.5)$ & $2(3.0)$ & $2(3.0)$ & $6^{*}(9.1)$ & $5^{*}(7.6)$ \\
\hline
\end{tabular}

a 5-point scale / Skala 5-stopniowa.

${ }^{*} \mathrm{Chi}^{2}$ test / test $\mathrm{Chi}^{2}, \mathrm{p}<0.0001$. 
Table 3. Risk factors for self-reported olfactory impairment (SROI) of workers occupationally exposed to phenolic resins univariate analysis

Tabela 3. Czynniki ryzyka zgłoszenia upośledzenia węchu (SROI) przez pracowników zawodowo narażonych na żywice fenolowe analiza jednoczynnikowa

$\begin{array}{lccc}\text { Variable } & \text { Respondents } & \mathrm{p} & \\ \text { Zmienna } & \text { Badani } & \left(\mathrm{Chi}^{2}\right) & \mathrm{OR}\end{array}$

\begin{tabular}{|c|c|c|c|c|}
\hline \multicolumn{5}{|l|}{ SROI $(\mathrm{N}=30)$} \\
\hline smoking / palenie papierosów & $11(36.7)$ & 0.484 & 1.702 & $0.580-4.998$ \\
\hline female sex / płeć żeńska & $6(20.0)$ & 0.022 & 4.118 & $1.340-12.65$ \\
\hline nasal surgery / operacja nosa & $7(23.3)$ & 0.125 & 4.480 & $0.855-23.474$ \\
\hline nasal trauma / uraz nosa & $10(33.3)$ & 0.317 & 2.121 & $0.668-6.739$ \\
\hline head trauma / uraz głowy & $12(40.0)$ & 0.334 & 1.950 & $0.670-5.672$ \\
\hline head surgery / operacja głowy & $3(10.0)$ & 0.034 & 2.172 & $1.663-2.838$ \\
\hline seniority $\geq 5$ years / staż pracy $\geq 5$ lat & $20(66.7)$ & 0.439 & 1.667 & $0.624-4.449$ \\
\hline age $>40$ years / wiek $>40$ lat & $18(60.0)$ & 0.617 & 1.446 & $0.568-3.816$ \\
\hline \multicolumn{5}{|l|}{ Hyposmia / Hiposmia (N = 21) } \\
\hline smoking / palenie papierosów & $8(38.1)$ & 0.396 & 1.902 & $0.625-5.787$ \\
\hline female sex / płeć żeńska & $6(28.6)$ & 0.918 & 2.031 & $0.541-7.260$ \\
\hline nasal surgery / operacja nosa & $4(19.0)$ & 0.624 & 1.882 & $0.450-7.882$ \\
\hline nasal trauma / uraz nosa & $9(42.9)$ & 0.036 & 4.071 & $1.249-12.275$ \\
\hline head trauma / uraz głowy & $10(47.6)$ & 0.040 & 3.182 & $1.051-9.634$ \\
\hline head surgery / operacja głowy & $1(4.8)$ & 1.000 & 1.075 & $0.092-12.562$ \\
\hline seniority $\geq 5$ years / staż pracy $\geq 5$ lat & $12(57.1)$ & 1.000 & 1.067 & $0.375-3.034$ \\
\hline age $>40$ years / wiek $>40$ lat & $12(57.1)$ & 0.718 & 1.394 & $0.491-3.957$ \\
\hline \multicolumn{5}{|l|}{ Anosmia $(\mathrm{N}=12)$} \\
\hline smoking / palenie papierosów & $5(41.7)$ & 0.331 & 2.041 & $0.557-7.481$ \\
\hline female sex / płeć żeńska & $5(41.7)$ & 0.640 & 1.696 & $0.468-6.151$ \\
\hline nasal surgery / operacja nosa & $4(33.3)$ & 0.046 & 4.900 & $1.080-22.233$ \\
\hline nasal trauma / uraz nosa & $5(41.7)$ & 0.236 & 2.792 & $0.742-10.505$ \\
\hline head trauma / uraz głowy & $6(50.0)$ & 0.196 & 2.857 & $0.791-10.326$ \\
\hline head surgery / operacja głowy & $2(16.7)$ & 0.144 & 10.600 & $0.876-128.331$ \\
\hline seniority $\geq 5$ years / staż pracy $\geq 5$ lat & $6(50.0)$ & 0.196 & 0.929 & $0.253-3.412$ \\
\hline age $>40$ years / wiek $>40$ lat & $8(66.7)$ & 0.400 & 2.154 & $0.579-8.011$ \\
\hline \multicolumn{5}{|l|}{ Hyperosmia / Hiperosmia $(\mathrm{N}=9)$} \\
\hline smoking / palenie papierosów & $3(33.3)$ & 1.000 & 1.281 & $0.285-5.751$ \\
\hline female sex / płeć żeńska & $6(66.7)$ & $<0.0001$ & 27.081 & $3.093-236.657$ \\
\hline nasal surgery / operacja nosa & $2(22.2)$ & 0.776 & 2.041 & $0.351-11.854$ \\
\hline nasal trauma / uraz nosa & $1(11.1)$ & 0.568 & 0.350 & $0,040-3.037$ \\
\hline head trauma / uraz głowy & $1(11.1)$ & 0.338 & 0.250 & $0.029-2.147$ \\
\hline head surgery / operacja głowy & $1(11.1)$ & 0.876 & 3.438 & $0.279-42.400$ \\
\hline seniority $\geq 5$ years / staż pracy $\geq 5$ lat & $7(77.8)$ & 0.293 & 3.150 & $0.602-16.448$ \\
\hline age $>40$ years / wiek $>40$ lat & $6(66.7)$ & 0.535 & 2.071 & $0.472-9.100$ \\
\hline
\end{tabular}

$\mathrm{N}$ - respondents / badani, OR - odds ratio / iloraz szans, CI - confidence interval / przedział ufności. 
Table 4. Self-reported olfactory impairment (SROI) of workers occupationally exposed to phenolic resins depending on the working site - multivariate regression analysis

Tabela 4. Zgłoszenia upośledzenia węchu (SROI) przez pracowników zawodowo narażonych na żywice fenolowe w zależności od miejsca pracy - wieloczynnikowa analiza regresji

\begin{tabular}{|c|c|c|c|c|c|c|}
\hline \multirow{3}{*}{$\begin{array}{l}\text { Variable } \\
\text { Zmienna }\end{array}$} & \multicolumn{6}{|c|}{$\begin{array}{l}\text { Study group } \\
\text { Grupa badana }\end{array}$} \\
\hline & \multicolumn{2}{|c|}{$\begin{array}{l}\text { shipping plant } \\
\text { wysyłkownia } \\
(\mathrm{N}=19)\end{array}$} & \multicolumn{2}{|c|}{$\begin{array}{l}\text { production plant } \\
\text { zakład produkcyjny } \\
(\mathrm{N}=32)\end{array}$} & \multicolumn{2}{|c|}{$\begin{array}{l}\text { mixing plant } \\
\text { mieszalnia } \\
(\mathrm{N}=15)\end{array}$} \\
\hline & $\mathrm{n}(\%)$ & OR (95\% CI) & $\mathrm{n}(\%)$ & OR (95\% CI) & $\mathrm{n}(\%)$ & OR $(95 \% \mathrm{CI})$ \\
\hline SROI & $7(36.8)$ & $1.000(\mathrm{REF})$ & $14(43.8)$ & $1.333(0.416-4.276)$ & $11(73.3)$ & $4.714(1.077-20.626)$ \\
\hline Hyposmia / Hiposmia & $6(31.6)$ & $1.000(\mathrm{REF})$ & $9(28.1)$ & $0.848(0.246-2.920)$ & $6(40.0)$ & $1.444(0.351-5.947)$ \\
\hline Anosmia & $1(5.3)$ & $1.000(\mathrm{REF})$ & $4(12.5)$ & $2.571(0.266-24.887)$ & $7(46.7)$ & $15.750(1.652-150.141)$ \\
\hline Hyperosmia / Hiperosmia & $1(5.3)$ & 1.000 (REF) & $5(15.6)$ & $3.333(0.359-30.948)$ & $3(20.0)$ & $4.500(0.417-48.531)$ \\
\hline
\end{tabular}

$\mathrm{N}$ - respondents / badani, REF - reference group / grupa referencyjna.

Other abbreviations as in Table 3 / Inne skróty jak w tabeli 3.

Table 5. Self-reported olfactory impairment (SROI) of workers occupationally exposed to phenolic resins and personal risk factors multivariate logistic regression analysis

Tabela 5. Zgłaszane upośledzenie węchu (SROI) przez pracowników zawodowo narażonych na żywice fenolowe a osobowe czynniki ryzyka - wieloczynnikowa analiza regresji logistycznej

\begin{tabular}{|c|c|c|c|}
\hline $\begin{array}{l}\text { Variable } \\
\text { Zmienna }\end{array}$ & $\mathrm{p}$ & $\mathrm{OR}_{\mathrm{a}}^{*}$ & $95 \% \mathrm{CI}^{*}$ \\
\hline \multicolumn{4}{|l|}{ SROI } \\
\hline female sex / płeć żeńska & 0.009 & 5.622 & $1.525-20.722$ \\
\hline nasal surgery / operacja nosa & 0.275 & 2.783 & $0.443-17.492$ \\
\hline nasal trauma / uraz nosa & 0.567 & 1.534 & $0.355-6.625$ \\
\hline head trauma / uraz głowy & 0.453 & 1.670 & $0.438-6.369$ \\
\hline production plant / zakład produkcyjny & 0.079 & 3.902 & $0.856-17.788$ \\
\hline mixing plant / mieszalnia & 0.188 & 2.935 & $0.592-14.567$ \\
\hline \multicolumn{4}{|l|}{ Hyposmia / Hiposmia } \\
\hline female sex / płeć żeńska & 0.967 & 1.027 & $0.289-3.647$ \\
\hline nasal surgery / operacja nosa & 0.982 & 0.981 & $0.183-5.269$ \\
\hline nasal trauma / uraz nosa & 0.124 & 2.919 & $0.746-11.427$ \\
\hline head trauma / uraz głowy & 0.310 & 1.967 & $0.533-7.251$ \\
\hline production plant / zakład produkcyjny & 0.686 & 1.341 & $0.323-5.571$ \\
\hline mixing plant / mieszalnia & 0.900 & 1.105 & $0.230-5.311$ \\
\hline \multicolumn{4}{|l|}{ Anosmia } \\
\hline female sex / płeć żeńska & 0.381 & 2.034 & $0.415-9.968$ \\
\hline nasal surgery / operacja nosa & 0.261 & 2.822 & $0.462-17.246$ \\
\hline nasal trauma / uraz nosa & 0.649 & 1.566 & $0.227-10.808$ \\
\hline head trauma / uraz głowy & 0.546 & 1.762 & $0.280-11.084$ \\
\hline production plant / zakład produkcyjny & 0.037 & 5.274 & $1.102-25.240$ \\
\hline mixing plant / mieszalnia & 0.045 & 11.133 & $1.060-116.929$ \\
\hline
\end{tabular}


Table 5. Self-reported olfactory impairment (SROI) of workers occupationally exposed to phenolic resins and personal risk factors multivariate logistic regression analysis - cont.

Tabela 5. Zgłaszane upośledzenie węchu (SROI) przez pracowników zawodowo narażonych na żywice fenolowe a osobowe czynniki ryzyka - wieloczynnikowa analiza regresji logistycznej - cd.

\begin{tabular}{lccc}
\hline \multicolumn{1}{c}{$\begin{array}{c}\text { Variable } \\
\text { Zmienna }\end{array}$} & $\mathrm{p}$ & $\mathrm{OR}_{\mathrm{a}}^{*}$ & \\
\hline Hyperosmia / Hiperosmia & & & \\
female sex / płeć żeńska & 0.007 & 25.143 & $2.379-265.700$ \\
nasal surgery / operacja nosa & 0.504 & 2.218 & $0.214-23.102$ \\
nasal trauma / uraz nosa & 0.636 & 0.524 & $0.036-7.583$ \\
head trauma / uraz głowy & 0.568 & 0.464 & $0.033-6.480$ \\
production plant / zakład produkcyjny & 0.409 & 2.328 & $0.313-17.307$ \\
mixing plant / mieszalnia & 0.630 & 2.038 & $0.112-36.969$ \\
\hline
\end{tabular}

OR - adjusted odds ratio / skorygowany iloraz szans.

* The adjusted odds ratios (with respective 95\% CIs) were obtained through a regression analysis model controlled for respondents' ethnicity, years of education, age, and total years of exposure / Skorygowane ilorazy szans (wraz z ich 95\% CI) otrzymano poprzez analizę regresji dla pochodzenia etnicznego, wykształcenia, wieku i czasu narażenia badanych.

Other abbreviations as in Table 3 / Inne skróty jak w tabeli 3.

and among the various QODs the hyperosmia was the most frequently complained about (8/21 vs. $1 / 44$ in males, $\mathrm{p}<0.0001)$. In general, the self-reported hyposmia was associated with previous nasal trauma $(\mathrm{p}=0.036 ; \mathrm{OR}=4.07 ; 95 \% \mathrm{CI}: 1.25-12.26)$ and head trauma $(\mathrm{p}=0.040 ; \mathrm{OR}=3.18$; 95\% CI: 1.051-9.634).

When the exposure groups were taken into account (Table 4), the SROI (OR $=4.71 ; 95 \%$ CI: $1.08-20.63$ ) were more frequently complained about by workers from the mixing plant, exhibited more frequently, in particular in terms of the anosmia $(7 / 15, \mathrm{OR}=15.75$; 95\% CI: 1.65-150.14).

When the multivariate model was applied (Table 5), taking into account ethnicity, age and working age as covariates and assuming a declining exposure from the mixing plant to the shipping plant (the latter workers assumed to be the referent ones), female sex was confirmed as the main determinant for the SROI $\left(\mathrm{OR}_{\mathrm{a}}=5.62 ; 95 \% \mathrm{CI}: 1.53-20.72\right)$ and the hyperosmia $\left(\mathrm{OR}_{\mathrm{a}}=25.14 ; 95 \% \mathrm{CI}: 2.38-265.7\right)$ whereas the self-complained anosmia was confirmed to be significantly more frequent in both of the exposed groups $\left(\mathrm{OR}_{\mathrm{a}}=5.27 ; 95 \% \mathrm{CI}: 1.10-25.24\right.$ for the production plant and $\mathrm{OR}_{a}=11.13$; 95\% CI: $1.06-116.93$ for the mixing plant).

\section{DISCUSSION}

Phenol is an irritating and corrosive substance, with skin and mucosal membranes as the main targets of its toxicity [17]. Because of the frequent co-exposure with formaldehyde, studies about human phenol toxicity remain ambiguous. Small statistically non-significant excess in mortality due to Hodgkin's disease and esophageal, renal and rectal cancers were previously suspected [17].

Two previous epidemiologic studies suggested a slight increase in mortality associated with respiratory cancers, hinting a direct effect on respiratory epithelia [25]. Baj et al., in a setting of low level chronic exposures to phenol (0.34 ppm), formaldehyde and isomers of organic chlorohydrocarbons used as a liquid wood preservative, identified the presence of chronic complaints, among them cough and sore throat, which is consistent with these results [26]. A high prevalence of neurological chronic complaints such as headache and fatigue was also identified. However, because of the mixed exposure settings, the authors suggested that the reported effects were more probably associated with the formaldehyde vapors [26].

The incidence of the QOD in the general population remains a matter of debate $[1,12,13]$ because most studies, like this one, used questionnaires to assess olfactory function rather than objective studies, so an accurate assessment remains difficult. The latter topic appears to be of particular interest focusing on the relatively high prevalence of previous head trauma complained about by the study population. For instance, head trauma is a frequent issue for general population, and it was repetitively acknowledged as a main risk factor for the QODs [10]. However, even assuming the higher estimates for head trauma in the general population (around 700 cases/100 000 in- 
habitants/year), the referred prevalence (30.3\%) remains questionably high, suggesting inaccurate recalling of personal history, and therefore questioning the consistence of a self-reporting assessment.

Quantitative olfactory disorders in occupational exposure to the PRs were previously well described [20,21]. However, these studies refer to working environments with a relatively high formaldehyde exposure, and reported complaints are more probably associated with formaldehyde levels. In our study, the co-exposure to phenols and formaldehyde was also identified but the relatively low levels of phenol and the very low exposure to formaldehyde hints that the clinical effects we identified were possibly associated with other exposures, the latter acting either as causative or contributory factors. In the initial study design, phenol exposure was assumed to be the most relevant one $[20,21]$.

However, thermal reactions are associated with the production of several other chemicals and airborne particulate (including fine and ultrafine fractions), both of them well acknowledged as detrimental for the $\mathrm{OE}$ (e.g., benzene and benzyl compounds, toluene, etc.) [11,12-16]. In fact, as environmental samples identified a similar pattern of exposure for formaldehyde/phenol on the one hand, and airborne particles on the other hand (Figure 1, Figure 2), these results may be interpreted rather as a consequence of the handling of the PRs than as a specific effect of phenol exposure.

Despite all the aforementioned limits and the small sample size (66 subjects), this remark may explain the relatively high prevalence of the SROI (45.5\%). Among them, a high ratio of the self-reported hyperosmia was identified, including the significantly higher prevalence in female sex. This remark is consistent with previous reports: despite the total surface of the $\mathrm{OE}$, the density of receptors and the mucosal expression of detoxification enzymes are similar in the two sexes, the sex-related difference in olfactory function has been widely reported, with women outperforming men, but also with female workers showing an increased sensitization to chemicals after prolonged occupational exposure, also at low levels $[12-15,26]$.

\section{CONCLUSIONS}

In our study of the occupational exposure to the PRs, sex appeared to be the main determinant for the SROI, namely it turned out to be more critical than factors more frequently associated with the anosmia/hyposmia (or even hyperosnia), such as smoking history, head and nasal trauma/surgery $[3,5,10,12,13]$. The main limitations of this study, the small sample size and the self-assessment of olfactory disorders, may partially explain these results.

First, because this study was questionnaire-based, we cannot rule out that the greater prevalence of olfactory disorders among female workers, which may reflect the greater attention to the health status, typically associated with female sex, rather than increased vulnerability of olfactory epithelium [29].

Second, because the reference group was drawn from the shipping/packaging plant, it reflects the gender composition of these physical demanding activities, with a higher representation of male workers [29-30]. This limitation could be compensated by enlisting a greater reference group, with a larger number of female workers not professionally exposed to chemicals (e.g., visual display of unit workers).

On the other hand, this option would increase the heterogeneity of the population, particularly regarding the education level, the psychosocial workload and the socioeconomic status, which at the moment is quite homogenous. As several studies previously stated, selfreporting of health symptoms is strictly associated with the education level and the socioeconomic status, and is deeply interconnected with psychosocial workload [30]. Eventually, instead of increasing the representation of female sex, enlarging the reference group with workers from a different setting would introduce another confounding factor, the control of which would require the study to be redesigned as a case-control one.

In conclusion, our questionnaire-based cross-sectional study has shown the increased prevalence of the SROI among workers from the abrasive industry, with a professional exposure to the PRs and, eventually, respiratory exposure to phenols and air particulate. In a multivariate model, female sex was associated with a significant increase in the SROI, and in particular the self-reported hyperosmia whereas levels of occupational phenol exposure appeared to be a more critical determinant for the self-reported one: because of the intrinsic limitations of this study (i.e., non-objective evaluation of the QOD, reduced sample size) clinical significance of this data should be cautiously evaluated $[12,13,15]$.

\section{REFERENCES}

1. Wysocki CJ, Gilbert AN. National geografic smell survey: Effects of age are heterogeneous. Ann N Y Acad 
Sci. 1989;561:12-28, http://dx.doi.org/10.1111/j.1749-6632. 1989.tb20966.x.

2. Landis BN, Konnerth CG, Hummel T. A study on the frequency of olfactory dysfunction. Laryngoscope. 2004;114:1764-9, http://dx.doi.org/10.1097/0000 5537-200410000-00017.

3. Lee WH, Wee JH, Kim D-K, Rhee C-S, Lee CH, Ahn S, et al. Prevalence of subjective olfactory dysfunction and its risk factors: Korean National Health and $\mathrm{Nu}-$ trition Examination Survey. PLOS ONE 2013;8:e62725, http://dx.doi.org/10.1371/journal.pone.0062725.

4. Bramerson A, Johansson L, Ek L, Nordin S, Bende M. Prevalence of olfactory dysfunction: The Skövde population based study. Laryngoscope. 2004;114:733-7, http://dx.doi.org/10.1097/00005537-200404000-00026.

5. Vennemann MM, Hummel T, Berger K. The association between smoking and smell and taste impairment in the general population. J Neurol. 2008;255:1121-6, http:// dx.doi.org/10.1007/s00415-008-0807-9.

6. Murphy C, Schubert CR, Cruickshanks KJ, Klein BEK, Klein R, Nondahl DM. Prevalence of olfactory impairment in older adults. JAMA. 2002;288:2307-12, http://dx.doi.org/10.1001/jama.288.18.2307.

7. Nordin S, Monsch AU, Murphy C. Unawareness of smell loss in normal aging and Azheimers' disease discrepancy between self-reported and diagnosed smell sensitivity. J Gerontol B Psychol Sci Soc Sci. 1995;50:P187-92, http://dx.doi.org/10.1093/geronb/50B.4.P187.

8. Shu CH, Lee PO, Lan MY, Lee YL. Factors affecting the impact of olfactory loss on the quality of life and emotional coping ability. Rhinology. 2011;49:337-41.

9. Henkin RI. Hyperosmia and depression following exposure to toxic vapors. JAMA. 1990;264:2803, http://dx.doi. org/10.1001/jama.1990.03450210103043.

10. Upadhyay UD, Holbrook EH. Olfactory loss as a result of toxic exposure. Otolaryngol Clin North Am. 2004;37: 1185-207, http://dx.doi.org/10.1016/j.otc.2004.05.003.

11. Amoore JE. Effects of chemical exposure on olfaction in humans. In: Barrow CS, editor. Toxicology of the nasal passages. New York: Hemisphere Publishing; 1986. p. 155-90.

12. Amoore JE, Hautala E. Odor as an aid to chemical safety: Odor threshold compared with threshold limit values and volatilities for 214 industrial chemicals in air and water dilution. J Appl Toxicol. 1983;3(6):272-90, http:// dx.doi.org/10.1002/jat.2550030603.

13. Hastings L, Miller ML. Olfactory loss secondary to toxic exposure. In: Seiden AM, editor. Taste and smell disorders. New York: Thieme; 1997. p. 88-106.

14. Smith DV, Duncan HJ. Primary olfactory disorders: Anosmia, hyposmia and dysosmia. In: Serby MJ, Cho- bor KL, editors. Science of olfaction. New York: SpringerVerlag; 1992. p. 439-66, http://dx.doi.org/10.1007/978-14612-2836-3_16.

15. Gobba F. Olfactory toxicity: Long-term effects of occupational exposures. Int Arch Occup Environ Health. 2006;79: 322-31, http://dx.doi.org/10.1007/s00420-005-0043-x.

16. Cowart BJ, Young IM, Feldman RS, Lowry LD. Clinical disorders of smell and taste. Occup Environ Med. 1997;12:465-9, http://dx.doi.org/10.1016/b978-0121619 58-9/50006-3.

17. Crawford J, Faroon O, Wilson J, Llados FT, Garber K, Paikoff SJ, et al., editors. Toxicological profile for phenol. Atlanta (GA): Agency for Toxic Substances and Disease Registry; 2008. p. 1-269.

18. Aust SD, Chignell CF, Bray TM, Kalyanaraman B, Mason RP. Free radicals in toxicology. Toxicol Appl Pharmacol. 1993;120:168-78, http://dx.doi.org/10.1006/taap. 1993.1100

19. Hisamitsu M, Yoshitaka O, Chazono H, Yonekura S, Sakurai D, Horiguchi S, et al. The influence of environmental exposure to formaldehyde in nasal mucosa of medical students during cadaver dissection. Allergol Int. 2011;60: 373-9, http://dx.doi.org/10.2332/allergolint.10-OA-0210.

20. Holmström M, Wilhelmsson B. Respiratory symptoms and pathophysiological effects of occupational exposure to formaldehyde and wood dust. Scand J Work Environ Health. 1988;14:306-11, http://dx.doi.org/10.5271/ sjweh.1915.

21. Holmström M, Rosen G, Wilhelmsson B. Symptoms, airway physiology and histology of workers exposed to medium-density fiber board. Scand J Work Environ Health. 1991;17:409-13, http://dx.doi.org/10.5271/sjweh.1685.

22. Fasunla AJ, Douglas DD, Adeosun AA, Steinbach S, Nwaorgu OGB. Effect of strong fragrance on olfactory detection threshold. Otolaryngol Head Neck Surg 2014;151:438-42, http://dx.doi.org/10.1177/01945 99814536851.

23. Swenberg JA, Moeller BC, Lu K, Rager JE, Fry RC, Starr TB. Formaldehyde carcinogenicity research: 30 years and counting for mode of action, epidemiology, and cancer risk assessment. Toxicol Pathol 2013;41:181-9, http:// dx.doi.org/10.1177/0192623312466459.

24. Nielsen GD, Larsen ST, Wolkoff P. Recent trend in risk assessment of formaldehyde exposures from indoor air. Arch Toxicol 2012;87:73-98, http://dx.doi.org/10.1007/ s00204-012-0975-3.

25. Dosemeci M, Blair A, Stewart PA, Chandler J, Trush MA. Mortality among industrial workers exposed to phenol. Epidemiology. 2006;2:188-93, http://dx.doi. org/10.1097/00001648-199105000-00005. 
26. Baj Z, Majewska E, Zeman K, Pokoca L, Dworniak D, Paradowski $\mathrm{M}$, et al. The effect of chronic exposure to formaldehyde, phenol and organic chlorohydrocarbons on peripheral blood cells and the immune system in humans. J Investig Allergol Clin Immunol. 1994;4:186-91.

27. National Institute for Occupational Safety and Health. Formaldehyde by VIS: Method 3500. In: Eller PM, Cassinelli ME, editors. NIOSH manual of analytical methods. 4th ed. Cincinnati (OH): The Institute; 1994.

28. National Institute for Occupational Safety and Health. Cresol (all isomers) and phenol: Method 2546. In: NIOSH manual of analytical methods. 4th ed. Cincinnati $(\mathrm{OH})$ : The Institute; 1994.
29. Zibrowski EM. Olfactory sensitivity in medical laboratory workers occupationally exposed to organic solvent mixtures. Occup Med. 2006;56:51-4, http://dx.doi. org/10.1093/occmed/kqi190.

30. Poulsen OM, Persson R, Kristiansen J, Andersen LL, Viliadsen E, Ørbaek P. Distribution of subjective health complaints, and their association with register based sickness absence in the Danish working population. Scand J Public Health. 2013;41:150-7, http://dx.doi. org/10.1177/1403494812471909.

31. Ree E, Odeen M, Eriksen HR, Indahl A, Ihlebaek C, Hetland J, et al. Subjective health complaints and self-rated health: Are expectancies more important than socioeconomic status and workload? Int J Behav Med. 2014;21: 411-20, http://dx.doi.org/10.1007/s12529-013-9329-7.

This work is available in Open Access model and licensed under a Creative Commons Attribution-NonCommercial 3.0 Poland License / Ten utwór jest dostępny w modelu open access na licencji Creative Commons Uznanie autorstwa - Użycie niekomercyjne 3.0 Polska - http://creativecommons.org/ licenses/by-nc/3.0/pl/deed.en. 